\title{
Hubungan Parameter Koagulasi dengan Tipe, Ukuran, dan Jumlah Perdarahan pada Operasi Tumor Otak Supratentorial
}

\author{
Endy Sugiyanto*), Dewi Yulianti Bisri**) \\ ${ }^{*}$ Departemen Anestesiologi dan Terapi Intensif Rumah Sakit Kesrem Meulaboh Aceh Barat, ${ }^{* *}$ Departemen \\ Anestesiologi dan Terapi Intensif Fakultas Kedokteran Universitas Padjadjaran-RSUP Dr. Hasan Sadikin Bandung
}

\begin{abstract}
Abstrak
Latar Belakang dan Tujuan: Tumor otak memiliki angka kejadian 3,8-5,5\% dari semua kasus tumor di Indonesia. Kebanyakan kasus tumor otak mengalami hiperkoagulasi, meskipun terdapat pengecualian pada beberapa kasus. Tujuan penelitian untuk mengetahui hubungan koagulopati dengan tipe, ukuran, dan jumlah perdarahan pada operasi tumor otak supratentorial

Subyek dan Metode: Penelitian observasional analitik pada 30 pasien dengan rancangan cross-sectional pengukuran berulang untuk menganalisis hubungan antara koagulopati dengan tipe, ukuran, dan perdarahan tumor otak. Pengambilan sampel penelitian dilakukan secara consecutive sampling

Hasil: Terdapat 17 orang pasien dengan meningioma, 2 orang pasien dengan oligodendroglioma, 3 orang pasien dengan metastase dan 8 orang dengan tumor lain. Rata-rata bleeding time, clotting time, protrombin time (PT), dan activated partial thromboplastin time (APTT) preoperatif, 2 jam dan 6 jam post operatif berada dalam rentang nilai normal. Ditemukan penurunan yang konstan pada dataAPTT. Terdapat hubungan negatifyang signifikan antara ukuran tumor dengan bleeding time preoperatif serta hubungan yang signifikan antara jumlah pendarahan dengan APTT preoperatif. Simpulan: Pasien tumor otak mungkin mengalami kondisi hiperkoagulasi dari hasil pemeriksaan faktor koagulasi sederhana, terdapat hubungan negatif antara ukuran tumor dan bleeding time sehingga semakin besar ukuran tumor semakin besar juga risiko hiperkoagulasi yang mungkin dialami pasien.
\end{abstract}

Kata kunci: Tumor Otak, Koagulopati, Hemostasis, Ukuran, Jenis, Perdarahan

JNI 2019;8 (2): 83-9

\section{Correlation between Coagulation Parameter and Type, Size, and Blood Loss in Supratentorial Brain Tumor Surgery}

\begin{abstract}
Background and Objective: The incidence rate of brain tumor 3.8-5.5\% of all tumor cases in Indonesia. Most of brain tumor patients experience hypercoagulation, although there are exception in some cases. The purpose of this study to know the relationship between coagulopathy and brain tumor supratentorial type, size, and number of bleeding on operation.

Subject and Methods: This is an observational analytical cross-sectional design for 30 patient to analyze correlation between coagulopathy and brain tumor type, size, and bleeding. The sampling methods were consecutive sampling Result: There were 17 patients with meningioma, 2 patients with oligodendroglioma, 3 patients with metastasis and 8 patients with other type of tumor. The average of bleeding time, clotting time, protrombin time (PT), dan activated partial thromboplastin time (APTT) in preoperative, 2 hours and 6 hours were normal. There were constant decline of APTT. Negative correlation between tumor size and preoperative bleeding time and significant correlation between amount of bleeding and preoperative APTT were also found. Conclusion: From simple coagulation factor test result, it is very like for a brain tumor patient to experience hypercoagulative state, a negative correlation between tumor size and bleeding time, meaning the bigger the tumor size, the higer hypercoagulation risk possesed by the patient.
\end{abstract}

Key words: Brain tumor, coagulopathy, hemostasis, size, type, bleeding

JNI 2019;8 (2): 83-9 


\section{Pendahuluan}

Central Brain Tumor Registry of United States (CBTRUS) mendefinisikan tumor otak sebagai tumor yang berlokasi di sistem saraf pusat (SSP) dan meningen kecuali limfoma dan bentuk kelainan morfologi pada leukemia. ${ }^{1}$ Angka kejadian tumor SSP dan mata di Indonesia berdasarkan Riset Kesehatan Dasar tahun 2013 mencapai 3,8-5,5\% dari semua kasus tumor. ${ }^{2}$ Tumor otak meliputi $85-90 \%$ dari seluruh tumor SSP. Glioblastoma multiforme (GBM) merupakan tumor otak dengan angka tertinggi mencapai $38 \%$. Meningioma dan tumor mesenkim sebanyak $27 \%$ dan sisanya terdiri dari tumor otak primer lain seperti tumor hipofisis, schwanoma, limfoma SSP, oligodendroglioma, ependimoma, astrositoma derajat rendah, dan meduloblastoma. ${ }^{3}$ Komplikasi akibat pertumbuhan tumor dapat berupa venous tromboembolism (VTE), emboli paru, perdarahan, disseminated intravascular coagulation (DIC), dan gangguan koagulasi maligna (Sindrom Trousseau). Komplikasi tersebut disebabkan karena pertumbuhan tumor berpengaruh terhadap fungsi vaskular dan koagulasi. ${ }^{4-6}$

Telah terbukti bahwa sel tumor dapat memproduksi prokoagulan dan sitokin yang mampu menginisiasi proses koagulasi. ${ }^{7,8}$ Tumor otak berpengaruh terhadap sistem hemostasis dan sebaliknya sistem hemostatis berpengaruh terhadap pertumbuhan tumor. Jenis tumor, stadium tumor, dan pertumbuhan tumor berpengaruh terhadap sistem hemostasis..$^{9,10}$ Beberapa tumor maligna juga mampu mengaktivasi fibrinolitik. Disregulasi hemostasis pada penderita tumor disebabkan karena ketidakseimbangan inhibitor koagulasi/fibrinolik plasma. Peningkatan tissue factor pathway inhibitor (TFPi) dan penurunan konsentrasi antitrombin (AT) dan kofaktor heparin II (HCII) yang terdeteksi pada penderita kanker terutama stadium lanjut.?

Disregulasi koagulasi pada pasien dengan tumor telah diidentifikasi oleh beberapa peneliti. Penelitian terhadap 50 penderita tumor otak primer untuk mengidentifikasi perubahan hemostatis selama operasi menggunakan metode
Thrombelastograph $\AA \quad(T E G \AA)$ menyimpulkan bahwa sebagian besar pasien mengalami hiperkoagulabilitas selama operasi, sebanyak $22 \%$ pasien mengalami abnormal TEG intraoperatif, $6 \%$ mengalami hematoma, dan $4 \%$ mengalami DIC. ${ }^{11}$ Identifikasi perubahan hemostatik pada operasi tumor dan fokus kejang pada anak menggunakan metode TEG ${ }^{\circledR}$ menyimpulkan bahwa terdapat hiperkoagulabilitas setelah operasi dilakukan. ${ }^{12}$

Penelitian pada 79 pasien tumor solid di Rumah Sakit Sanglah Bali telah berhasil mengungkapkan bahwa semakin tinggi stadium klinis tumor solid, semakin tinggi kadar D dimer (DD) plasma. ${ }^{13}$ Disregulasi vaskular dan koagulasi akibat tumor otak dapat berpotensi sebagai penyulit pada manajemen preoperatif, intraoperatif dan pascaoperatif. Tindakan operasi sangat berisiko dilakukan pada penderita gangguan koagulasi karena berpotensi menyebabkan perdarahan dan hematom pascaoperasi yang berkaitan dengan morbiditas dan mortalitas. Oleh karena itu, pemeriksaan seperti hemoglobin, prothrombin time (PT), partial thromboplastin times (PTT), fibrinogen degradation product (FDP) dan D dimer (DD) perlu dilakukan. ${ }^{11}$ Pemeriksaan PT dan APTT merupakan pemeriksaan yang sering dilakukan untuk mengidentifikasi gangguan koagulasi. ${ }^{12}$

Berdasarkan studi pendahuluan yang peneliti lakukan di ruang operasi Rumah Sakit Hasan Sadikin (RSHS) Bandung dalam kurun waktu satu tahun terakhir terdapat terdapat lebih dari 144 kasus tumor yang menjalani operasi, oleh karena itu peneliti bermaksud meneliti hubungan koagulopati berdasarkan nilai CT, BT, PT, dan APTT dengan tipe, ukuran, dan jumlah perdarahan pada operasi tumor otak supratentorial. Tujuan penelitian ini adalah mengkaji hubungan koagulopati dengan tipe, ukuran dan jumlah perdarahan pada tumor otak supratentorial.

\section{Subjek dan Metode}

Penelitian ini menggunakan desain penelitian observasional analitik dengan rancangan crosssectional dengan pengukuran berulang untuk 
menganalisis hubungan antara koagulopati dengan jenis tumor otak. Penelitian ini dilakukan dari bulan Oktober 2017 hingga bulan Februari 2018. Subjek penelitian ini adalah pasien tumor otak supratentorial di ruang rawat inap Bagian Bedah Saraf RSHS. Kriteria inklusi meliputi pasien tumor otak primer yang dibuktikan dengan hasil pemeriksaan computed tomography scan (CT-scan), jenis tumor otak supratentorial, pasien belum pernah menjalani operasi di bagian kepala, dan bersedia mengikuti prosedur penelitian yang dibuktikan dengan penandatanganan informed consent.

Kriteria eksklusi pada penelitian ini adalah pasien memiliki riwayat penyakit kelainan darah, penyakit kardiovaskular, penyakit hati, penyakit ginjal, diabetes mellitus, pasien dalam kondisi hamil, dan memiliki riwayat konsumsi obat antikoagulan dan hemostatik. Penentuan besar sampel disesuaikan dengan tujuan penelitian dan tipe data pada penelitian yaitu penelitian ini bertujuan untuk mencari hubungan antara koagulopati dengan berbagai jenis tipe tumor otak, maka dengan menggunakan rumus penentuan besar sampel untuk penelitian analitis korelatif numerik maka didapatkan jumlah sampel 30 orang. Pengambilan sampel penelitian dilakukan secara purposive sampling.

Penelitian dilakukan setelah mendapatkan persetujuan oleh Komite Etik Penelitian Kesehatan Fakultas Kedokteran Universitas Padjadjaran/ RSUP Dr. Hasan Sadikin Bandung. Semua subjek penelitian yang memenuhi kriteria inklusi dan tidak termasuk kriteria eksklusi menjalani pemeriksaan histologi dari sampel jaringan tumor, pengukuran tumor melalui CTscan, serta pemeriksaan koagulasi berupa BT, CT, PT, dan APTT preoperatif, 2 jam pascaoperatif, dan 6 jam postoperatif. Penghitungan jumlah perdarahan dilakukan saat operasi melalui tangki suction, jumlah kassa yang berdarah, lapangan operasi, dan jumlah darah ditampung ke baskom penampungan yang dialasi plastik.

Data yang berskala numerik dipresentasikan dengan rerata dan standar deviasi, nilai maksimal, dan nilai minimal. Data karakteristik disajikan dalam bentuk distribusi frekuensi dan persentase. Untuk menganalisis hubungan antara usia, ukuran tumor dan jumlah pendarahan dengan parameter koagulopati digunakan analisis korelasi rank Spearman, sedangkan untuk menganalisis perbedaan parameter koagulopati berdasarkan tipe tumor digunakn uji Kruskal-Wallis, dan untuk membandingkan parameter koagulopati dari ketiga waktu pengulangan digunakan uji Friedman. Interpretasi dari besarnya koefisien korelasi berdasarkan kriteria Guilford yaitu jika $\mathrm{r}$ antara $0,0-0,199=$ sangat lemah; $0,20-0,399=$ lemah; $0,40-0,599=$ sedang; $0,6-0,799=$ kuat; dan $0,80-1,000=$ sangat kuat. Kemaknaan hasil uji ditentukan berdasarkan nilai $\mathrm{p}<0,05$. Semua data dicatat pada formulir khusus dan dianalisis secara statistik dengan program SPSS versi 21.0 for Windows.

\section{Hasil}

Penelitian dilakukan terhadap 30 pasien yang menjalani operasi kraniotomi tumor removal elektif di RSUP Dr. Hasan Sadikin Bandung dari bulan Oktober 2017 sampai Januari 2018. Sebagian besar subjek penelitian adalah perempuan (70\%), dengan usia berkisar antara 13 sampai 66 tahun, ukuran tumor terkecil $5 \mathrm{~mm}^{3}$ dan terbesar $238 \mathrm{~mm}^{3}$, jumlah pendarahan berkisar antara $400 \mathrm{cc}$ sampai $1000 \mathrm{cc}$, dan tipe tumor sebagian besar meningioma (57\%).(Tabel 1)

Tabel 2 menyajikan perbedaan parameter koagulasi dari ketiga pengukuran preoperatif, 2 jam postoperatif dan 6 jam postoperatif. Dari tabel tersebut didapatkan data parameter koagulasi tidak berdistribusi normal, maka untuk membandingkan perbedaan parameter koagulopati digunakan uji statistik Friedman, hasilnya didapatkan bahwa BT, CT dan PT antara ketiga waktu pengukuran tidak menunjukkan perbedaan yang bermakna $(p>0,05)$; sedangkan untuk APTT ada perbedaan yang bermakna $(p<0,05)$, walaupun dari ukuran mediannya tidak jauh berbeda.

Tabel 3 menyajikan hitungan korelasi untuk hubungan antara usia, ukuran tumor, jumlah pendarahan dengan parameter koagulopati. Dari 
Tabel 1. Karakteristik Subjek Penelitian $(n=30)$

\begin{tabular}{lc}
\hline Karakteristik & Ukuran Statistik \\
\hline Jenis kelamin & 9 \\
Laki-laki & 21 \\
Perempuan & \\
Usia (tahun): & $43,3(10,5)$ \\
Rerata (SD) & 44 \\
Median & $13-66$ \\
Rentang & \\
Ukuran tumor (mm $\left.{ }^{3}\right)$ & $58,3(52,9)$ \\
Rerata (SD) & 38,8 \\
Median & $5-238$ \\
Rentang & \\
Jumlah pendarahan (cc): & $623,3(209,6)$ \\
Rerata (SD) & 500 \\
Median & $400-1000$ \\
Rentang & 17 \\
Tipe tumor: & 2 \\
Meningioma & 3 \\
Oligondendroglioma & 8 \\
Metastase & \\
Tumor Lain &
\end{tabular}

empat parameter koagulasi hanya APTT yang berkorelasi positif dengan jumlah pendarahan $(\mathrm{r}=$

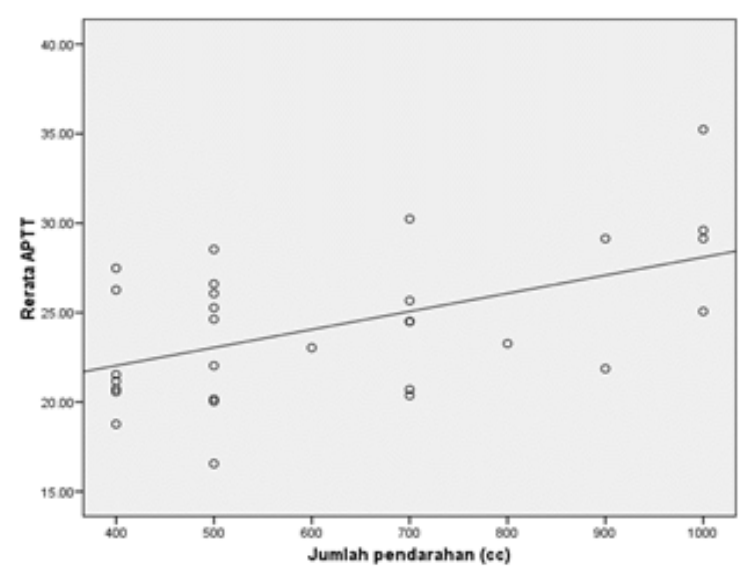

Gambar 1. Korelasi antara Jumlah Pendarahan dengan Rerata APTT

0,428; $\mathrm{p}=0,018)$; dengan korelasi yang bermakna $(\mathrm{p}<0,05)$ Hasil uji statistik dengan uji KruskalWallis didapatkan bahwa parameter koagulasi pada beberapa tipe tumor tidak menunjukkan adanya perbedaan yang bermakna $(\mathrm{p}>0,05)$. (Tabel 4)

\section{Pembahasan}

Pasien dengan tumor otak supratentorial dapat bervariasi berdasarkan dari tipe tumor, lokasi tumor, ukuran tumor dan kedekatan lokasi tumor

Tabel 2. Perbandingan Faktor Koagulasi pada berbagai Waktu Pengukuran

\begin{tabular}{|c|c|c|c|c|}
\hline \multirow[b]{2}{*}{ Variabel } & \multicolumn{3}{|c|}{ Waktu pengukuran } & \multirow[b]{2}{*}{ Nilai $p^{*}$} \\
\hline & Pre operatif & 2 jam post operatif & 6 jam post operatif & \\
\hline Bleeding Time (menit) & & & & 0,729 \\
\hline Median & 1 & 1 & 1 & \\
\hline Rentang & $1-15$ & $1-130$ & $1-2$ & \\
\hline Clotting Time (menit) & & & & 0,658 \\
\hline Median & 3 & 3 & 3 & \\
\hline Rentang & $3-4$ & $1,3-3,5$ & $3-3,5$ & \\
\hline $\begin{array}{l}\text { Prothrombine Time } \\
\text { (detik) }\end{array}$ & & & & 0,422 \\
\hline Median & 11,6 & 10,8 & 10,9 & \\
\hline Rentang & $9,8-13,8$ & $4,9-25,1$ & $0,8-17,3$ & \\
\hline APTT (detik) & & & & 0,001 \\
\hline Median & 24,4 & 23,9 & 22,4 & 22,4 \\
\hline Rentang & $18,9-36,8$ & $16,0-40,6$ & $1,07-34,5$ & \\
\hline
\end{tabular}

Keterangan: ${ }^{*}$ ) berdasarkan uji Friedman; APTT preoperatif vs 2 jam postoperatif : $p=0,436$; preoperatif vs 6 jam postoperatif : $\mathrm{p}=0,002 ; 2$ jam vs 6 jam postoperatif: $\mathrm{p}=0,016$. 
Tabel 3. Korelasi Usia, Ukuran tumor, Jumlah pendarahan dengan rerata Parameter Koagulopati

\begin{tabular}{lllllll}
\hline \multirow{2}{*}{ Parameter Koagulopati } & \multicolumn{2}{c}{ Usia } & \multicolumn{3}{c}{ Ukuran Tumor } & \multicolumn{2}{c}{ Jumlah Pendarahan } \\
\cline { 2 - 7 } & \multicolumn{1}{c}{ Nilai P } & $\mathrm{r}$ & $\mathrm{N}$ Nilai $\mathrm{p}$ & $\mathrm{r}$ & Nilai P \\
\hline Bleeding Time (menit) & $-0,045$ & 0,813 & $-0,120$ & 0,529 & 0,056 & 0,770 \\
Clotting Time (menit) & 0,303 & 0,104 & $-0,087$ & 0,646 & 0,268 & 0,152 \\
$\begin{array}{l}\text { Median } \\
\text { Rentang }\end{array}$ & 3,17 & & & 3,25 & 3,17 & \\
$\begin{array}{l}\text { Prothrombine } \\
\text { (detik) }\end{array}$ & $3-3,43$ & & & $3,17-3,33$ & $3-3,33$ & \\
APTT (detik) & 0,046 & 0,808 & 0,033 & 0,861 & $-0,146$ & 0,441 \\
\hline & $-0,056$ & 0,767 & 0,109 & 0,568 & 0,428 & 0,018 \\
\hline
\end{tabular}

Keterangan : $r=$ koefisien korelasi rank Spearman

Tabel 4. Perbandingan Parameter Koagulasi berdasarkan Tipe Tumor

\begin{tabular}{|c|c|c|c|c|c|}
\hline \multicolumn{6}{|c|}{ Tipe tumor } \\
\hline Parameter Koagulopati & $\begin{array}{l}\text { Meningioma } \\
\quad(n=17)\end{array}$ & $\begin{array}{l}\text { Olig o n d e n - } \\
\text { droglioma } \\
(\mathrm{n}=2)\end{array}$ & $\begin{array}{l}\text { Metastase } \\
\quad(n=3)\end{array}$ & $\begin{array}{l}\text { Tumor lain } \\
\qquad(\mathrm{n}=8)\end{array}$ & Nilai $p^{*}$ ) \\
\hline \multicolumn{6}{|l|}{ Bleeding Time (menit) } \\
\hline Median & 1,33 & 1 & 1 & 1,17 & 0,306 \\
\hline Rentang & $1-44,33$ & 1 & $1-1,5$ & $1-1,67$ & \\
\hline \multicolumn{6}{|l|}{ Clotting Time (menit) } \\
\hline Median & 3,17 & 3,25 & 3,17 & 3,17 & 0,612 \\
\hline Rentang & $3-3,43$ & $3,17-3,33$ & $3-3,33$ & $2,43-3,33$ & \\
\hline $\begin{array}{l}\text { Prothrombine } \\
\text { (detik) }\end{array}$ & & & & & \\
\hline Median & 11,8 & 10,4 & 13,3 & 11,2 & 0,254 \\
\hline Rentang & $10,0-15,4$ & $10,4-10,4$ & $10,5-14,5$ & $5,3-16,7$ & \\
\hline APTT (detik) & & & & & 0,001 \\
\hline Median & 24,5 & 21,6 & 27,5 & 24,8 & 24,8 \\
\hline Rentang & $16,6-30,2$ & $20,0-23,3$ & $20,6-35,2$ & $18,8-29,1$ & \\
\hline
\end{tabular}

dengan struktur vital misalnya batang otak. Oleh karena itu, data mengenai keadaan pasien sangat penting yang meliputi, tingkat kesadaran, tanda dan gejala dari kenaikan tekanan intrakranial, gangguan sensoris dan motoris, serta ada dan tidaknya gejala kejang perlu dinilai. Jenis tumor supratentorial yang sering terjadi adalah meningioma, glioma, kista koloid ventrikular atau basal cistern epidermoids. Secara teknis, operasi meningioma sangat berhubungan dengan risiko pendarahan yang signifikan dibandingkan dengan glioma. Oleh karena itu pemeriksaan CT-scan dan MRI diperlukan untuk menilai karakterisitik tumor yang meliputi ukuran, vaskularitas, lokasi dan kenaikan tekanan intrakranial.

Hasil penelitian ini menunjukkan tipe tumor tidak menunjukkan perbedaan bermakna dari keempat parameter koagulasi. Demikian juga ukuran tumor tidak ada hubungan bermakna dengan keempat parameter koagulasi, namun terdapat kecenderungan semakin besar ukuran tumor semakin meningkat nilai APPT. Selanjutnya, hubungan jumlah pendarahan dengan keempat 
parameter koagulasi, hanya nilai APTT yang menunjukkan hubungan positif bermakna dengan jumlah pendarahan $(r=0,428)$ yang termasuk kriteria korelasi sedang. Hal ini sesuai dengan hipotesis penelitian sebelumnya yang menyatakan bahwa tumor berukuran besar justru dapat menyebabkan keadaan hipokoagulasi yang memicu perdarahan, salah satunya akibat disseminated intravascular coagulopathy. ${ }^{11}$

Terganggunya proses koagulasi pada tumor juga dapat diakibatkan sel kanker yang tersirkulasi di darah, limfatik dan keduanya yang memicu adhesi sel kanker pada endotelium vaskular sehingga akan membentuk trombus. Pembentukan fibrin akan meningkatkan konsumsi fibrin yang sangat berperan dalam menentukan besarnya ukuran tumor, akibatnya faktor koagulasi akan terganggu yang menyebabkan ukuran tumor semakin besar akibat deposit fibrin tersebut. ${ }^{15}$ Keadaan normal pada penelitian ini dapat pula disebabkan oleh keadaan kompensasi dalam proses hemostasis yaitu keadaan hiperkoagulasi tubuh untuk mengurangi jumlah pendarahan dan respons tumor untuk memperbesar ukurannya. Hal tersebut juga dipengaruhi oleh beberapa stimulus seperti proses operasi, terapi radiasi atau infeksi. ${ }^{15}$ Beberapa penelitian telah meneliti tentang faktor risiko hiperkoagulasi pada pasien tumor otak dengan menggunakan pemeriksaan penunjang lain yang dapat menunjukkan kondisi dan risiko terjadinya kelainan koagulasi pada pasien tumor otak. Contohnya adalah pemeriksaan TEG yang dapat menilai keadaan defisiensi faktor koagulasi yang tidak dapat terlihat dari nilai PT maupun APTT hingga terdapat penurunan lebih dari 50\%. ${ }^{11}$ Faktor dan produk trombogenesis juga merupakan biomarker potensial untuk menilai risiko hiperkoagulasi pasien tumor otak. Beberapa plasmamarker yang mungkin meningkat adalah D-dimer, lipoprotein, homocystein, tPA dan PAI- $1 .{ }^{16}$ Terdapat tiga faktor utama yang terlibat dalam proses koagulasi dari kanker. Pertama, gangguan hemostasis vaskular yang berlangsung secara kronis akan menyebabkan gangguan pada jaringan yang diakibatkan pertumbuhan tumor, seperti gangguan angiogenesis yang persisten, inflamasi kronis, ektravasasi cel sumsum tulang dan metastasis tumor pada ruang vaskular. ${ }^{5}$ Keadaan tersebut akan meningkatkan kontak dengan vaskular yang akan memicu keadaan koagulasi. Kedua, gangguan koagulasi dapat dicetuskan oleh pengobatan dari kanker tersebut. Misalnya, intervensi teurapeutik seperti operasi, radiasi dan administrasi kemoterapi sistemik dan agen antiangiogenik, penempatan dari akses vena sentral serta stasis yang diakibatkan dari tirah baring yang akan membentuk kondisi prokoagulan. ${ }^{5}$ Ketiga, akibat dari agen biologikal tumor itu sendiri mengubah keadaan menjadi prokoagulan. Tumor yang berasal dari beberapa bagian otak, selnya masing-masing memiliki kemampuan untuk mengaktifkan koagulasi. ${ }^{5}$ Contohnya, pada keadaan sistemik yang disebabkan tumor glioblastoma (GBM) mengekspresikan molekular-molekular yang mengaktifkan gen koagulasi (coagulome) seperti proneural (PN), neural (NEU), classical (CL) dan penyakit messenkimal (MES). Pada tumor meduloblastoma pun mengekspresikan molekular pengaktivasi koagulasi seperti wingless (WNT), sonic hedhehog (SHH), group 3 (G3) dan group 4 (G4). Pada akhirnya, setiap tumor di berbagai lokasi di otak mempunyai sistem koagulasi yang berbeda sehingga perlu di lakukan penelitian lebih lanjut mengenai peran koagulasi pada tumor otak yang berhubungan dengan koagulasi. ${ }^{5}$ Keterbatasan pada penelitian ini adalah tidak dilakukan pemeriksaan lanjutan mengenai faktor koagulasi yaitu berupa penilaian TEG, faktor koagulasi kuantitatif, dan kualitatif yang dikarenakan keterbatasan penunjang dan peneliti akan pemeriksaan tersebut.

\section{Simpulan}

Penelitian ini menunjukkan hubungan positif antara koagulopati dengan ukuran tumor dan jumlah perdarahan tumor otak supratentorial. Hal ini secara sederhana dapat dikatakan sebagai bukti keadaan hiperkoagulasi pada pasien tumor otak, meskipun kebenarannya masih perlu dibuktikan dengan pemeriksaan lain dengan spesifitas dan sensitivitas yang lebih baik. Pemeriksaan faktor koagulasi secara rutin dapat menentukan prognosis pasien dengan tumor otak dalam menilai respon koagulasi. Penilaian 
ukuran tumor juga menentukan prognosis khususnya dalam menangani pasien sehingga diharapkan dapat mempunyai kualitas hidup yang lebih baik. Penelitian lanjutan mengenai kondisi kelainan koagulasi pada pasien dengan tumor otak menggunakan pemeriksaan penunjang yang lebih spesifik seperti TEG dan plasma marker diperlukan untuk memperkuat penelitian ini.

\section{Daftar Pustaka}

1. Ostrom QT, Gittleman H, Farah P, Ondracek A, Chen Y, Wolinsky Y, dkk. CBTRUS statistical report: Primary brain and central nervous system tumors diagnosed in the United States in 2006-2010. Neuro-oncology. 2013;15(suppl 2):ii1-ii56.

2. Oemiati R, Rahajeng E, Kristanto AY. Prevalensi tumor dan beberapa faktor yang mempengaruhinya di Indonesia. Buletin Penelitian Kesehatan. 2011; 39(4 Des): 190204.

3. Kanker KNP. Panduan Nasional Penanganan Kanker: Tumor Otak. Edisi. Jakarta: Kementerian Kesehatan Republik Indonesia; 2015.

4. Cote DJ, Smith TR. Venous thromboembolism in brain tumor patients. Journal of Clinical Neuroscience. 2016;25:13-8.

5. D'Asti E, Fang Y, Rak J. Brain neoplasms and coagulation-lessons from heterogenecity. Rambam Maimonides Medical Journal. 2014;5(4).

6. Perry JR. Thromboembolic disease in patients with high-grade glioma. Neuro-oncology. 2012;14(supp14):iv73-iv80.

7. Sierko E, Wojtukiewicz MZ, Kisiel W, editors. The role of tissue factor pathway inhibitor-2 in cancer biology. Seminars in thrombosis and hemostasis; 2007: (C) Thieme Medical Publishers.

8. Zhu J-F, Cai L, Zhang X-W, Wen Y-S, Su
X-D, Rong T-H, dkk. High plasma fibrinogen concentration and platelet count unfavorably impact survival in non-small cell lung cancer patients with brain metastases. Chinese journal of cancer. 2014;33(2):96.

9. Kvolik S, Jukic M, Matijevic M, Marjanovic K, Glavas-Obrovac L. An overview of coagulation disorders in cancer patients. Surgical oncology. 2010;19(1):e33-e46.

10. Falanga A, Marchetti M, Vignoli A. Coagulation and cancer: biological and clinical aspects. Journal of Thrombosis and Haemostasis. 2013;11(2):223-33.

11. Goh KY-C, Tsoi W-C, Feng C-S, Wickham N, Poon WS. Haemostatic changes during surgery for primary brain tumours. Journal of Neurology, Neurosurgery \& Psychiatry. 1997;63(3):334-8.

12. Goobie SM, Soriano SG, Zurakowski D, McGowan FX, Rockoff MA. Hemostatic changes in pediatric neurosurgical patients as evaluated by thrombelastograph ${ }^{\circledR}$. Anesth Analg. 2001;93(4):887-92.

13. Suega K, Bakta IM. Correlation between clinical stage of solid tumor and D dimer as a marker of coagulation activation. Acta Med Indones. 2011;43(3):162-7.

14. Sivanaser V, Manninen P. Preoperative assessment of adult patients for intracranial surgery. Anesthesiology research and practice. 2010.

15. Sun NC, McAfee WM, Hum GJ, Weiner JM. Hemostatic abnormalities in malignancy, a prospective study of one hundred eight patients: Part I. Coagulation studies. American Journal of Clinical Pathology. 1979;71(1):10-6.

16. Jo JT, Schiff D, Perry JR, editors. Thrombosis in brain tumors. Seminars in thrombosis and hemostasis; 2014: Thieme Medical Publishers. 